\title{
Stanisław Wszołek
}

\section{Some Remarks on Lukasiewicz's Philosophical Method}

Since the time of the first philosophers of nature, philosophy has undergone many changes. Though some would dispute whether this discipline makes any progress nobody could deny that philosophical debate is following a certain path and moving towards certain conclusions. Philosophical thinking develops because philosophy, like other sciences, is commonly regarded as an emending quest for knowledge, a constant attempt to establish a body of truths about the universe and ourselves. Since this ambitious attempt often fails to achieve its ends, one can see the changes in philosophy as successive answers given to the demand for a new method. The perspective of adopting a new method, the need for which is particularly felt at each turning point, has always been connected with the hope that it is possible to transform philosophy into science, episteme, in the sense familiar to the Greeks.

At the beginning of the 20th century, when Lukasiewicz entered the current philosophical discussion, philosophy had been getting over one of its most difficult periods. This time the threat came from psychology which started to take the place of 'transcendental epistemology', the latter being unable to cope with new problems (Ayer 1984, chapter 2). The whole process suggested the justified worry about the future of philosophy as a science, so much so that some critics started to voice opinions about its death. That it turned out to be premature is to be ascribed to a radical turn towards logic. Here is the comment of R. Rorty: „Just as mathematics had inspired Plato to invent 'philosophical thinking', some serious- minded philosophers turned to mathematical logic for rescue from the exuberant satire of their critics" (Rorty 1979, p. 116). Rorty mentions E. Husserl and B. Russell, the two philosophers who caused the turn. We need to add at least one more name, that of the great logician G. Frege, 
whose writings on the foundations of mathematics, though not generally appreciated at once, exerted a tremendous influence upon many fine thinkers of the time. ${ }^{1}$ The essential point is that the turn towards logic, connected with the discovery of the importance of language for philosophy, brought about the new philosophical method: analysis. Philosophical analysis, though understood differently by various philosophers or philosophical schools, was regarded as a standard method by almost all currents of the so-called ,analytical philosophy". Slowly, the analysis of language assumed the role of 'first philosophy', a foundational discipline in the Aristotelian sense of the word. A. J. Ayer, a British exponent of the Vienna Circle, summed this up in these words:

The propositions of philosophy are not factual, but linguistic in character, that is, they do not describe the behavior of physical, or even mental objects; they express definitions, or the formal consequences of definitions. Accordingly, we may say that philosophy is a department of logic. (Ayer 1946, p. 57)

Ayer echoed R. Carnap, a pupil of G. Frege and great system-building formalist of the Vienna Circle, whose central thesis read that ,the logic of science takes the place of the inextricable tangle of problems which is known as philosophy" (Carnap 1967, p. 279). It was also in Carnap that the notion scientific philosophy appeared as the possible term to apply to the discipline he had tried to build. Both terms, analysis and scientific philosophy, so explicitly associated with logical empiricism, were used by Lukasiewicz too. He spoke about 'scientific philosophy' as the renewed philosophy of the future. He also stressed the method of logical analysis as the appropriate method for philosophical research. ${ }^{2}$

However, any suggestion that Łukasiewicz's use of these terms involves a commitment to the opinions of philosophers like Carnap, is definitely misleading. Łukasiewicz's analysis cannot be identified with

${ }^{1}$ That the contribution of Frege was of great importance we can learn from the following facts. Husserl in his first important work Philosophy of Arithmetic (1891) tried to derive the basic concepts of arithmetic from psychological principles. However, soon after, in the Prolegomena to a Pure Logic, which forms the first volume of his Logical Investigations (19001901), he not only abandoned his previous project, but directed vivid attack against 'psychologism'. Many have claimed that the change was due to Frege's review of his first book Philosophy of Arithmetic.

${ }^{2}$ Lukasiewicz, as we know, shifted his interests from philosophy to mathematical logic because of its method. One who reads his papers todacy cannot ignore the emphasis he puts on the adjective 'scientific' when he writes about 'scientific philosophy', or 'scientific method' that he believes to have found in logic. He saw himself as a man who experienced personally 'that specific joy' which, being due to the method of analysis, accompanied a correct solution to a uniquely formulated problem (Łukasiewicz 1961, p. 202). 
Carnap's analysis of language. The leading philosopher of the Vienna Circle tried to construct an idealized language of science, capable of expressing all scientific propositions. In order to do this he tried to reduce all authentic problems to the questions of language. Being fully aware of the weight of Carnap's approach, Łukasiewicz considered it to be ,a risky philosophical speculation which will die away as all similar speculations have died away" (Łukasiewicz 1961, p. 207, 1970, p. 233). His own analysis is of a different sort. Perhaps, the best way to present the differences between Carnap and Łukasiewicz is to show their different attitudes towards philosophy.

R. Rorty has recently introduced the Philosophy-philosophy distinction in order to represent divergent stances towards philosophy (Rorty 1982, see: introduction). Philosophy with a capital-P, originated by Plato, denotes ,,a special inquiry into the nature of certain normative notions (e.g. 'truth', 'rationality', 'goodness') in the hope of better obeying such norms". Rorty's alternative is philosophy with a small-p. He sets Socrates against Plato and favours 'socratic philosophy' which consists in informal and wide-ranging conversation (Rorty 1979, p. 317; 1982, p. XVI).

Viewed in terms of Rorty's distinction ${ }^{3}$, Carnap, despite his interests concentrated on language, is still held captive by Plato's fundamentalist picture of philosophy. From the very outset (Die logische Aufbau der Welt) Carnap intends to construct a rational basis for inductive sciences. What Russell did with regard to mathematics, he tries to accomplish with regard to the language of empirical sciences. Łukasiewicz, on the other hand, does not seem to have any foundational ambitions. Although he says that 'scientific philosophy' must start its own construction from ,the foundation", his understanding of the process of construction is by no means consonant with that of Carnap. Łukasiewicz's project of reforming philosophy does not embrace the whole of philosophy. In particular, he proposes to select first those philosophical problems that „,can be formulated in a comprehensive manner". Then, he intends to analyse them with the help of mathematical logic. As a result Łukasiewicz expects to have a number of formalized theories-answers to particular philosophical problems and not just one basic system like Carnap's Konstitutionssystem (Carnap 1961, p. 262). He would agree with Carnap and even more recently expressed Dummett's desire to turn philosophy into an exact science. That is the reason why he likes the notion of 'scientific philosophy'. But as he convincingly opposed Carnap's idea that scientific philoso-

${ }^{3}$ We should add that the Philosophy-philosophy distinction is not a fortunate one. We mention it to simplify our discussion. 
phy amounts to the logic of science, so in the same way he would reject Dummett's idea that philosophy amounts to the foundational theory of meaning (Dummett 1973 , p. 76). Lukasiewicz's desire to reform philosophy cannot be read as a foundational claim. In fact, he does not seek any ,natural-starting-point” of thought, independent of any presupposition. On the contrary, his idea of reforming philosophy is based on the fundamental assumption that we should spell out all suppositions before approaching a specific sort of problems with the axiomatic method. Łukasiewicz, like Popper, starts with philosophical problems (Popper 1972, p. 160-161). Since philosophical problems are different from the problems investigated by natural science, he is ready to recognize the specific character of philosophy which, as a whole, is „something apart from science”. In practice however, his method approaches the method of science. It seems that he tries to combine the deductive method of logic with the method employed by empirical sciences as the proper method for philosophy (Kamiński [979, p. 2s6). As a result philosophy, though 'scientific', cannot assume the status of „first philosophy”.

This becomes even clearer when we consider Lukasiewicz's methodological remarks about science. As early as in 1912 he opposed strongly the traditional view which he summarized in the following words:

Both scientists and those who are remote from science often deem that the goal of science is truth, and they understand truth as agreement between thought and existence. Hence they think that the scientist's work consists in reproducing facts in true judgments, similarly as a photographic plate reproduces light and shadow and a phonograph reproduces sound. The poet, the painter, and the composer work creatively, the scientist does not create anything, but merely discovers the truth (Lukasiewicz 1970, p. 1).

Łukasiewicz himself, in clear opposition to this view, emphasizes 'creative elements in science': scientific propositions do not reproduce facts that are empirically given, but „,are manifestations of man's creative thought” or ,products of the human mind". He sees the role of experience in being ,, a stimulus for creative ideas”, and providing ,subjects for their verification"4. Reading this article of 1912 one may be surprised to which extent it anticipates Popper's ideas on induction, verification or falsification and probability. The conclusion that emerges from these remarks is the following: Given the fact that science is not able to provide definite answers how can we expect philosophy to be a discipline of ,eternal truths".

This fact, however, should not open him to the charge of relativism in philosophy. Though opposing the view of philosophy with capital-P, Łuka-

\footnotetext{
${ }^{4}$ Łukasiewicz adds that conclusive verification happens only exceptionally.
} 
siewicz does not assume Rorty's relativistic position (Putnam 1983, p. 235). Rorty shares one assumption with the positivists; he thinks that philosophical problems are not real problems. He also identifies truth with right assertability by some cultural standards. That is because he reads the history of philosophy as a series of successive failures to make sense out of the core philosophical notion of 'correspondence to reality' (Rorty 1979, p. 317). It is pointless to repeat that Łukasiewicz would never agree with these opinions. He would also dissent from Wittgenstein's view that philosophy is a kind of therapy and has no need of science or scientific tools (Wittgenstein 1953, p. 18). For him as for Russell, to equate philosophy with therapy is to trivialize it. Russell in 1914, arguing that philosophical method ought to be scientific, wrote that ,philosophy is the science of the possible”, for its propositions ,must be concerned with such properties of all things as do not depend upon the accidental nature of the things that there happen to be, but are true of any possible world, independently of such facts as can only be discovered by our senses" (Russell 1963, p. 84). In the course of the argumentation Russell came to the conclusion that philosophy and logic coincide. With much of this Łukasiewicz would agree. Philosophy, in his opinion too, is not in competition with science in offering a general view of reality or adding a scientific account of its own special sets of objects. But philosophy and logic cannot be the same. They must be separated for philosophy, in its attention to logical forms, must also be sensitive to factual or empirical data.

As we can see, Łukasiewicz's position is not easy to account for. One may even argue that, developed to the extremes, it might reveal some contradictory features. Leaving this to the judgement of the reader we prefer to point in another direction. In our opinion, Łukasiewicz, by the fact of leaving the issue unfinished, does justice to some difficulties emerging from the Philosophy-philosophy distinction. For he states clearly that, if philosophy is to play any role in the search of knowledge, it has to be 'scientific' philosophy, i.e., a discipline able to obtain and verify its achievements. On the other hand, however, he explicitly considers as a failure any foundationalist claim. As the result he obtains a possible mosaic of axiomatized sets of different issues very often being only loosely connected with one another. From the occasional remarks that we can find in his writings we know that he wants philosophy to be able to deal with its problems piece by piece, resolving them separately. He even - and here we can see to what extent his ideas anticipate Popper's - thinks that philosophy, like other sciences, obtains only partial and probably not wholly correct results which can be utilized and improved by subsequent 
investigations. The force of the axiomatic method is manifest in this context. Every small problem thoroughly analysed and clearly formulated (formalized) can be used as a basis for further research. A scientific philosophy, then, such as he wishes it to support, is a piece by piece and tentative investigation of philosophical problems.

Of course, this possibility of successive approximations to the truth stands in clear opposition to the conception of philosophy as a "first discipline". In comparison with Carnap or Dummett's foundational attempts Łukasiewicz's method promises no ultimate explanation of any philosophical problem. It also disagrees with the conception of philosophy as a kind of cultural conversation. If we adopt this standpoint, it will certainly cause our uneasiness. However, we daresay that Lukasiewicz's position avoids a common assumption shared by both the supporters of philosophy with capital-P (as is the case of Carnap and Dummett) and the adherents of philosophy with small-p (favoured by Wittgenstein or Rorty). This common assumption reads: in both cases, whether we aim at obtaining the secure fundament of knowledge or whether we renounce it as a matter of principle, our solutions are more the mark of a smug complacency that all is all right than a signal of the advance of human thought As Putnam observes, both Carnap's pure scientism and Rorty's relativism (,hidden scientism”) are dangerous for philosophy. We have reason to think that Łukasiewicz would very much agree with this opinion. If not, i.e., if we are mistaken in our interpretation of Łukasiewicz's thought, then this is the point we cannot share with him. In this case we should like to oppose his ,scientific" tendencies using the same arguments we mentioned above against his potential adversaries.

\section{References}

Ayer Alfred J. 1946, Language, Truth and Logic, London: Golach.

Ayer Alfred J. 1984, Philosophy in the Twentieth Century, London: Unwin Paperbacks. Carnap Rudolf 1961 [1928], Die logische Aufbau der Welt. Scheinprobleme in der Philosophie, Hamburg: F. Meiner Verlag.

Carnap Rudolf 1967 [1937], The Logical Syntax of Language, London: Routledge \& Kegan Paul Ltd.

Dummett Michael 1973, Truth and Other Enigmas, London: G. Duckworth. Kamiński Stanisław 1979, „Łukasiewicza koncepcja metody filozofii”, Roczniki

Filozoficzne 21, pp. 283-289. 
Łukasiewicz Jan 1912, „0 twórczości w nauce” [in:] Księga pamiątkowa ku uczczeniu 250 rocznicy założenia Uniwersytetu Lwowskiego, Lwów, pp. 1-15.

Łukasiewicz Jan 1961, Z zagadnień logiki i filozofii, Warszawa: PWN.

Łukasiewicz Jan 1970, Selected Works, edited by Borkowski L., Amsterdam- Warszawa: North-Holland Publishing Company-PWN.

Passmore John 1985, Recent Philosophers, London: G. Duckworth.

Popper Karl R. 1972, Objective Knowledge, Oxford: Clarendon Press.

Putnam Henry 1983, Realism and Reason, Cambridge: Cambridge University Press.

Rorty Richard 1979, Philosophy and the Mirror of Nature, Princeton: Princeton University Press.

Rorty Richard 1982, Consequences of Pragmatism (Essays: 1972-1980), Minneapolis: University of Minnesota Press.

Russell Bertrand 1963, „On scientific method in philosophy”, [in:] Mysticism and Logic, London: Unwin Books.

Wittgenstein Ludwig 1953, The Blue and Brown Books, Oxford: Oxford University Press.

Stanisław Wszołek Institute of Philosophy Tarnów, Poland 